\title{
Lesson Planning The Key to Success of The Teachers Teaching in Class
}

\author{
Martono \\ Universitas Tanjungpura \\ martono_fkipuntan@yahoo.co.id
}

\begin{abstract}
Successful teacher is a teacher who can establish a sympathetic relationship with the students, create a classroom environment that is nurturing, caring, has a love of learning, in full control of their field of study and to motivate students to work. To achieve that, the teacher should be able to prepare a good lesson planning. Lesson planning is a systematic process with respect to determining the learning objectives, strategies and techniques to achieve the goal, and the media that can be used for effective achievement of objectives. Lesson planning is the result of profound thought processes, the results of the assessment and selection process of the various alternatives that are considered to have more value for effectiveness and efficiency. Lesson planning is the beginning of all the process of a rational implementation of activities. Thus, the teacher must be able to visualize the direction and goals to be achieved and how to achieve these goals through the use of the potential that exists for the process of reaching that goal effectively and efficiently. The expectation that teachers realize how important lesson planning for a teacher. Not arbitrary in drawing up the planning of learning.
\end{abstract}

\section{Keywords-teacher, planning, learning}

\section{INTRODUCTION}

In the teaching and learning activities, a teacher becomes very important. Success in a highly determined by the learning skills of teachers in planning lessons. He should prepare a lesson plan, implement, and evaluate learning. Not easy to prepare, implement, and evaluate learning. To prepare a lesson plan, implement, and evaluate it required a very comprehensive understanding. Therefore, to be a good teacher competence is required. Council of Chief State School Officers (CCSSO) [1], creating a model Core Teaching Standards, the essential knowledge, performance, and disposition (inclination) to be owned by veteran teachers to ensure that all students learn.

There are four professional standards for teachers (1). teaching and learning. Teachers understand how students learn and develop as well as a learning experience. (2) Learning Materials. Teachers must have a deep understanding of what is taught and how to make materials that can be understood by students. (3) The teaching practice. Teachers must understand and integrate the planning, teaching practice, and assessment to promote learning for all students. (4) The responsibility of a professional.
Based on Law No. 20 Year 2003 on National Education System, Chapter XI, Article 39, paragraph (2) of educators are professionals in charge of planning and implementing the learning process, assessing the results of learning, coaching and training, and conduct research and dedication to the community, especially for educators at college. [2]

Learning success is largely determined by the skills of teachers in designing learning. If the teacher entered the class and teach without preparation, then he should be ready to out of the classroom without honor and dignity. [3] Professional teachers will be measured by the extent to which he can design learning and teaching it in a learning process in the classroom, so that students can achieve optimal learning results.

Teachers should focus his mind when planning a lessons. He should already know the final goal to be achieved. So that planning can be structured and well defined, then the goal should be formulated in the form of clear and measurable targets. With the clear goals, then there is a target to be achieved. Target's what subsequently became the focus in determining the next steps. Formulate how to get to the place that means preparing measures that are considered effective in the achievement of goals.

Teachers should be able to develop a lesson plan. The essence of the lesson plan is to design a set of actions that aim to change the existing situation to the desired situation. Likewise, instructional materials development, management and evaluation of learning activities, both process and outcome. In the real shape of these efforts is characterized by the formulation of operational competencies, selection and preparation of the subject matter to be taught and consistent with competence.

In addition, teachers also need to develop learning materials that will be given to students. Which is to be arranged in a hierarchical manner. Ranging from the simple to the difficult material. At the end of learning, what is taught is evaluated to determine the students' understanding of the material that has been provided by the teacher. Problem is given must refer to the purpose of learning. All activities should be designed by the teacher as well. all that is competencies required of a teacher. According to the Law No. 14 Year 2015 on Teachers and Lecturers, Article 10. 1. Teacher competency as referred to in Article 8 includes pedagogical competence, personal 
competence, social competence, and professional competence acquired through professional education. [4]

This paper discusses the importance of lesson planning. To find it, then do research related to the importance of planning for learning in school. The focus of this study is: How can understanding teachers on lesson planning? Will serve as the focus of research subfokus: a. How did the teachers undertand about the importance of planning for learning? b. Do teachers know what to do when writing lesson plans? To answer the focus of the study, carried out a survey to teachers. The teachers fills the instruments that have been prepared. The contents of the instrument relating to the planning, the importance of planning, how to prepare, and implement it in the classroom.

\section{LESSON PLANNING}

Lesson planning is a function that is essential for management and evaluation of learning and essentially depends on lesson plans that have been made by educators. Learning plan should be designed in a systematic way. Therefore, it is very important to know the nature of lesson planning.

Lesson planning as a process to establish the "where to go" and how to get to the "place" in a manner that most effectively and efficiently. [5] Assign 'where to go' has the same meaning formulate goals and objectives that will be addressed, while defining "how to get to the place of the" means along the steps that are considered effective in the achievement of goals.

Planning as an intellectual process to help teachers systematically analyze learner needs and construct structure possibilities to responsively address those needs. So therefore, a lesson plan geared to analyze the needs of students in learning and then attempt to assist in answering these needs. [6]

Planning is the result of profound thought processes, the results of the assessment process and may be the selection of the various alternatives that are considered to have more value for effectiveness and efficiency. Planning is the beginning of all the process of a rational implementation of activities. Thus, the planner should be able to visualize the direction and goals to be achieved and how to achieve these goals through the use of the potential that exists for the process of reaching that goal effectively and efficiently.

Teachers should be able to develop a learning plan. The essence of the learning plan is to design a set of actions that aim to change the existing situation to the desired situation. Likewise, instructional materials development, management and evaluation of learning activities, both process and outcome. In the real shape of these efforts is characterized by the formulation of operational competencies, selection and preparation of the subject matter to be taught and consistent with competence.

\section{LESSON PLANNING BENEFITS}

Learning plan is the result of the thinking process, meaning a learning plan prepared by considering all the aspects that can affect the success of the learning process. Lesson plans are prepared to alter the behavior of students in accordance with the objectives to be achieved. This means that the main focus in lesson planning is goal achievement.

Lesson planning benefits are as follows: [7]

- With careful planning and accurate, will be able to predict how much success can be achieved.

- As a means to solve the problem. With careful planning teacher easily anticipate problems that may arise.

- To take advantage of a variety of learning resources appropriately. Through planning, the teacher can determine the sources of learning what is considered appropriate for studying a study materials.

- Planning will be able to make the learning takes place systematically. that is, the learning process will not last pickup, but takes place in a focused and organized.

\section{RESEARCH METHOD}

The design of this study using quantitative research. With this design will be used to see the responses of teachers with regard to lesson planning. Teachers were asked how important lesson planning response that made the teacher for teaching and learning. For data retrieval researchers used the instrument in the form of a questionnaire.

The subjects were 25 teachers who teach in Pontianak. They are from a variety of teachers in High School a.k.a SMAN / vocational school and junior high school a.k.a SMPN. SMPN 1 there are two teachers, SMPN 2 there are two teachers, SMPN 3 there are two teachers, SMPN 8 there are two teachers, SMPN 10 there are two teachers. SMAN 1 there are 4 teachers, SMAN 2 there are three teachers, SMAN 3 there are 4 teachers, SMAN 4 there are 4 teachers.

Data collection techniques with indirect communication. The teachers fills the instruments provided by the researcher. There are ten questions given to teachers. Questions related to lesson planning. To determine the response of teachers on the first subproblem using five instruments (number 1, 2, 3, 9, 10). To determine the response of teachers on the second subproblem using five instruments (number 4, 5, 6, 7, 8). Having collected the instruments were calculated responses of the teachers. Subproblems analyzed based on research being focused on.

\section{RESULT AND DISCUSSION}

Based on the results of questionnaires that have been filled by the teacher, then the result can be described as follows.

Result

Based instruments that have been filled by teachers from schools in the city of Pontianak. There are 10 teachers from Junior High School and 15 teachers from High School . 
Teachers give feedback on lesson planning in research instruments.

- Lesson Planning is learning component that must be prepared before teaching. Teachers who choose the answer (A) strongly agree scored 3 . Teachers who chose this answer, there are 22 teachers $(88 \%)$. Teachers who choose answer (B) agreed scored 2. Teachers who chose this answer only 3 teachers (12\%). No teachers have an answer less agree and disagree. Based on the answers given by the teacher informed that they strongly agree and agree the lesson planning is a component that must be prepared teacher before teaching. This realization prove that they knew the lesson planing should prepare before teaching in the classroom.

- The success of teaching and learning activities in the classroom is also determined by the lesson planning. Teachers who choose the answer (A) strongly agree scored 3. Teachers who chose this answer, there are 23 teachers $(92 \%)$. Teachers who choose answer (B) agreed scored 2. Teachers who chose this answer there are two teachers $(8 \%)$. No teachers have an answer less agree and disagree. Based on the answers provided by the teacher proves that teachers strongly agree and agree the success of teaching and learning in the classroom is also determined by the teachers' lesson planning.

- Learning plan as a guide for teachers in the learning process. Teachers who choose the answer (A) strongly agree scored 3. Teachers who chose this answer there are 21 teachers $(84 \%)$. Teachers who choose answer (B) agreed scored 2 . Teachers who chose this answer only 4 teachers $(16 \%)$. No teachers have an answer less agree and disagree. This proves that the teachers strongly agree and agree that the learning plan as a guide for teachers in the learning process. The belief that the learning plan petrified teacher while in class.

- Activities that must be performed before writing a lesson plan teachers are seeing the curriculum, see the teaching materials, saw school supplies, discussions with colleagues. Teachers who choose the answer (A) strongly agree scored 3 . Teachers who chose this answer there are 24 teachers $(96 \%)$. Teachers who choose answer (B) agreed scored 2. Teachers who chose this answer just one teacher (4\%). No teachers have an answer less agree and disagree. The answer given by the teachers prove that teachers know what to do before writing lesson planning. Teachers have noticed and done that before writing lesson planning.

- In lesson planning, component materials, methods, media, and evaluation is very important. The components are to create learning objectives. Teachers who choose the answer (A) strongly agree scored 3 . Teachers who chose this answer there are 19 teachers $(76 \%)$. Teachers who choose answer (B) agreed scored 2. Teachers who chose this answer only $6(24 \%)$. No teachers have an answer less agree and disagree. Based on the answers provided by the teacher, to prove that the component materials, methods, and evaluation is very important because it can realize the goal of learning. The component that determines the whether or not the teacher made learning plan. The success of teaching and learning in the classroom is also determined at that component.

- Syllabus is a product development and learning curriculum that contains the outlines of learning materials. The principle of syllabus development for learning are: scientific, attention to the development and needs of students, systematic, relevant, consistent, and adequacy. Teachers who choose the answer (A) strongly agree scored 3. Teachers who chose this answer there are 17 teachers $(68 \%)$. Teachers who choose answer (B) agreed scored 2 . Teachers who chose this answer only eight teachers (32\%). No teachers have an answer less agree and disagree. Based on the answers given by the teacher, to prove their understanding of the principles of syllabus development for learning.

- Planning is the result of profound thought processes, the results of the assessment and selection process of the various alternatives that are considered to have more value for effectiveness and efficiency. Planning is the beginning of all the process of a rational implementation of activities. Thus, the planner should be able to visualize the direction and goals to be achieved and how to achieve these goals through the use of the potential that exists for the process of reaching that goal effectively and efficiently. Teachers who choose the answer (A) strongly agree scored 3 . Teachers who chose this answer there are 24 teachers. (96\%). Teachers who choose answer (B) agreed scored 2 . Teachers who chose this answer is only one (4\%). No teachers have an answer less agree and disagree. Based on the responses of teachers to prove their understanding of lesson planning. A planner should be able to visualize the direction and goals to be achieved and how to achieve these goals through the use of the potential that exists for the process of reaching that goal effectively and efficiently.

- Learning activities should be able to develop and improve: competence, creativity, independence, cooperation, solidarity, leadership, empathy, tolerance and life skills learners to form the character, as well as improving civilization and dignity of the nation. Teachers who choose the answer (A) strongly agree scored 3. Teachers who chose this answer, there are 20 teachers. (80\%). Teachers who choose answer (B) agreed scored 2 . Teachers who chose this answer only 5 people $(20 \%)$. No teachers have an answer less agree and disagree. Based on the answers of teacher, to prove that learning activities should develop and improve the competence, creativity, independence, cooperation, solidarity, leadership, empathy, tolerance, and life skills learners to help the character, as well as improving civilization and dignity of the nation.

- A teacher is a person who carry out teaching and learning activities. The teacher is not guided by the 
planning that do not fit the expected goals in the curriculum. Teachers who choose the answer (A) strongly agree scored 3 . Teachers who chose this answer, there are 18 teachers. (72\%). Teachers who choose answer (B) agreed scored 2. Teachers who chose this answer only seven teachers $(28 \%)$. No teachers have an answer less agree and disagree. Based on the answers given by teacher, to prove that their understanding of lesson planning. The teacher is not guided by the planning that is not in accordance with the overall objective of the curriculum.

- Teachers who do not master the material will be helped by existing lesson plans that were prepared. Teachers who choose the answer (A) strongly agree got 3 . Teachers who chose this answer there are 19 teachers $(76 \%)$. Teachers who choose answer (B) agreed scored two and there are six teachers $(24 \%)$. No teachers have an answer less agree and disagree. The answer given by the teacher to prove the benefits of planning for learning. Teachers who do not master the material will be helped by existing lesson plans that have been prepared.

Based on the analysis instrument that has been filled by a teacher, it can be concluded as follows.

A. Responses teachers about the importance of the learning plan can be seen by the instrument number (1, 2, 3, 9, 10) as follows.

- Instruments 1 . There are 22 teachers $(88 \%)$ answered strongly agree, and there are three teachers who answered agree (12\%) Lesson planning is learning component that must be prepared before teaching.

- Instruments 2. There are 23 teachers (92\%) answered strongly agreed, and the two teachers answered agree $(8 \%)$ the success of teaching and learning in the classroom is determined by teachers' lesson planning.

- Instruments 3. There are 21 teachers $(84 \%)$ answered strongly agreed, and 4 teachers answered agree $(16 \%)$ the lesson plan as a guide for teachers in the learning process.

- Instruments 9. There are 18 teachers (72\%) who answered strongly agree, and there are seven teachers $(28 \%)$ answered agree. teacher is a figure that other teaching and if teachers are not guided by the planning that has made it certainly will not correspond to the learning objectives.

- Instruments 10 . There are 19 teachers (76\%) who answered strongly agree and there are 6 teachers (24\%) answered agree. teachers who do not master the material will be helped with their lesson plan that has been prepared.

B. Competences of the teacher while writing lesson plans can be seen by the instrument number $(4,5,6,7,8)$.

- Insrtumen 4. There are 24 teachers (96\%) who answered strongly agree and there is one teacher who answered agreed. Activities that must be performed before writing a lesson plan is viewed curriculum, teaching materials, school supplies, discussions with colleagues.
- Instruments 5. There were 19 teachers (76\%) answered strongly agree and 6 teachers (24\%) answered agree in drawing up the lesson plan, the component materials, methods, media, and evaluation is very important to note.

- Instruments 6. There are 17 teachers (68\%) who answered a very important and 8 teachers (32\%) responded agreed that the syllabus is a product development and learning curriculum that contains the outlines of learning materials.

- Instruments 7. There are 24 teachers (96\%) answered strongly agree and 1 teacher answered agree (4\%), a planner should be able to visualize the direction and goals that must be achieved.

- Instruments 8 . There are 20 teachers (80\%) answered strongly agree and 5 teachers answered agree (20\%) that the learning activities should be able to develop and improve the competence, creativity, independence, cooperation, solidarity, leadership, empathy, tolerance and life skills learners

\section{CONCLUSSION}

Lesson planning is very important in the learning activities. Therefore, teachers must prepare draft of lesson planning properly. Teachers must pay attention to the curriculum used in order not to deviate from the purpose of learning.

Lesson planning is the result of the thinking process. Teachers who wrote the planning must consider a critical component that learning objectives can be achieved.

Pedagogical competence of teachers should be improved. Principals and education authorities must continue to pay attention to the competence of teachers in order not to decrease. Teachers should be given the opportunity to attend training and be able to join in MGMPs field of study.

\section{REFERENCE}

[1] Eggen, Paul and Don Kauchak. Strategies and Models for Learning: Teaching Content and Thinking Skills, 6 editions. translator: Satrio Wahono. 2012. Jakarta: PT Indeks.

[2] Law No. 20 Year 2003 on National Education System, Chapter XI, Article 39, paragraph (2)

[3] Mukhtar and Iskandar, 2010. Desain Pembelajaran Berbasis Teknologi Informasi dan Komunikasi (Sebuah Orientasi Baru). Jakarta: Gaung Persada Press.

[4] Law No. 14 Year 2015 on Teachers and Lecturers, Article 10. 1. Teacher competency as referred to in Article 8 includes pedagogical competence, personal competence, social competence, and professional competence acquired through professional education.

[5] Kaufman, Roger A. and Fenwick W. English. 1979. Need Asessment: Concept and Application. Englewood Cliffs: Educational Technology Publications.

[6] Sanjaya, Wina. 2008. Perencanaan dan Desain Sistem Pembelajaran. Jakarta: Kencana.

[7] Kemp, Jerrold E. 1994. Proses Perancangan Pengajaran. Penerjemah: Asril Marjohan. Bandung: ITB. 